UDC 691.542

Author: URKHANOVA Larisa Alekseevna, Doctor of Engineering, Professor, Head of Department «Production Of Building Materials And Articles», East Siberia State University of Technology and Management; Kluchevskaya st., 40 v, Ulan-Ude, Russian Federation, 670013, urkhanova@mail.ru; Author: SAVELYEVA Marina Aleksandrovna, Postgraduate of Department «Production of building materials and articles», East Siberia State University of Technology and Management; Kluchevskaya st., 40 v, Ulan-Ude, Russian Federation, 670013, senya160394@mail.ru

\title{
THE EFFECT OF DIFFERENT COMPOSITION SOLS ON CHANGE OF STRUCTURE AND PROPERTIES OF CEMENT STONE
}

\section{Extended Abstract:}

One of the most rapidly developing directions in science of structural materials is the application of nanotechnology for development of new generation concrete. To date, nanodispersed additives were widely used in technology of concrete, because they allow increasing its main physicalmechanical properties. The use of effective additives contained nanoparticles in its composition allows to optimize structure of concrete, and also to reduce a consumption of the most expensive component - cement. The need to make new available and rather inexpensive modifiers of cement and concrete products is due to the resource intensive, difficulty of its receiving, therefore, high cost and, respectively, a market price.

The article discusses the production of additives in the form of sols on the basis of the chemical elements of VI group of the periodic system of D.I. Mendeleev, in particular of sulfur and chromium, and its use for modification of cement stone. The main characteristics of aqueous solutions of sols were defined by physical and chemical methods of researches and calculation. The content of the colloid additives in cement stone was optimized as a result of the conducted experimental studies, it was determined that the kinetics of cement strength setting depends on the type and amount of sols. The content of sols in cement stone is about thousand fractions of binder mass, i.e. its strength increases at the microlevel. That gives significant saving of the presented additives when they are introduced into cement and concrete compositions. The use of additives of sols on the basis 
of compounds of sulfur and chromium not only accelerated hydration and hardening of cement in the early period, but also significantly improved the strength characteristics of cement stone. The received nanodispersed additives can be included in group of hardening-accelerating admixes of cement. The increasing of strength of a cement stone modified by sols of various compositions is a result of change of its structure. Electronic and microscopic analysis showed that use of sols of different composition as modifiers leads to compaction of microstructure of cement stone and formation of difficult compounds of sulfur and chromium with hydrated calcium silicates.

Key words: sulfur sol, chromium hydroxide sol, barium chromate sol, hydration, hardening, cement stone, compressive strength.

DOI: dx.doi.org/10.15828/2075-8545-2016-8-6-20-42

\footnotetext{
MAChine-Readable information on CC-licenses (HTML-CODE) IN METAdATA OF THE PAPER

$<$ a rel="license" href="http://creativecommons.org/licenses/by/4.0/" $><$ img alt="Creative Commons License" style="borderwidth:0" src="https://i.creativecommons.org/l/by/4.0/88x31.png" / $></ \mathrm{a}><$ br $/><$ span xmlns:dct="http://purl.org/dc/ terms/" href="http://purl.org/dc/dcmitype/Text" property="dct:title" rel="dct:type">The effect of different composition sols on change of structure and properties of cement stone $</$ span $>$ by $<$ a xmlns:cc="http://creativecommons.org/ns\#" href $="$ Nanotehnologii v stroitel'stve $=$ Nanotechnologies in Construction. 2016, Vol. 8, no. 6, pp. 20-42. DOI: dx.doi. org/10.15828/2075-8545-2016-8-6-20-42 " property="cc:attributionName" rel="cc:attributionURL">Urkhanova L.A., Savelyeva M.A. $</ a>$ is licensed under a $<$ a rel="license" href="http://creativecommons.org/licenses/by/4.0/" $>$ Creative Commons Attribution 4.0 International License $</ \mathrm{a}>$. $<$ br $/>$ Based on a work at $<$ a xmlns:dct="http://purl.org/dc/terms/" href=" http://nanobuild.ru/en_EN/nanobuild-6-2016/" rel="dct:source" $>$ http://nanobuild.ru/en_EN/nanobuild-6-2016/</ $\mathrm{a}>.<\mathrm{br} />$ Permissions beyond the scope of this license may be available at $<$ a xmlns:cc="http://creativecommons.org/ns\#" href="urkhanova@mail.ru" rel="cc:morePermissions" $>$ urkhanova@mail.ru $</ a>$.
}

oday there is an increasing interest attracted by use sol-gel technology in cement compositions and concrete for increase its main structural and technical properties: frost resistance, durability, water resistance, reduction shrinkage strains [1]. So far there was the significant amount of additives on the basis of silica acid sol, iron hydroxide sol, aluminum hydroxide sol which used for obtaining high-strength concrete due to structural change of material. The great contribution to studying of this direction was made by such scientists as M.M. Sychev, P.G. Komokhov, 
L.B. Svatovskaya, N.P. Lukutsova and etc. which received generally onecomponent sols and applied them for modification of cement and concrete [2-17]. Authors [18-21] received the sols included in its composition at the same time silica acid sol, iron hydroxide sol, aluminum hydroxide sol. They developed methods of receiving sols through exchange reactions between salts of multivalent metals.

The analysis of the periodic system of D.I. Mendeleev showed that to date there are a few studies focused on the production of sols based on chemical elements of VI group. The VI group contains chemical compounds which form sols of different composition and stability at hydrolysis or as a result exchange reactions. Authors of article conducted researches of cement stone modification by sols of different composition. Among them chemical compounds of sulfur and chromium are of interest because they are available and rather cheap.

The sulfur sol is a nanodispersed colloidal system which receiving is possible by two methods: redox reaction and solvent substitution method. By the last method the fat solution of sulfur is added gradually to liquid which well mixes up with solvent, for example, with acetone or ethanol, but it doesn't mix up with water.

Receiving of sulfur sol occurs at interaction of the strong acids with sodium thiosulfate by method of redox reaction. Free thiosulfuric acid breaks down with formation of elemental sulfur:

$$
\begin{aligned}
& 2 \mathrm{HCl}+\mathrm{Na}_{2} \mathrm{~S}_{2} \mathrm{O}_{3} \rightarrow 2 \mathrm{NaCl}+\mathrm{H}_{2} \mathrm{~S}_{2} \mathrm{O}_{3} . \\
& \mathrm{H}_{2} \mathrm{~S}_{2} \mathrm{O}_{3} \rightarrow \mathrm{S}+\mathrm{H}_{2} \mathrm{O}+\mathrm{SO}_{2} \uparrow .
\end{aligned}
$$

The formation of hydroxide of chromium (III) sol occurs as a result complete ion-exchange reaction - the irreversible hydrolysis proceeded at mixture of solutions of two salts reinforced hydrolysis of each other. Sedimentation with emission of carbon dioxide gas leads to formation turbidgreen hydroxide of chromium (III) sol:

$$
2 \mathrm{Cr}\left[((\mathrm{NO})]_{3}\right)_{3}+3 \mathrm{Na}_{2} \mathrm{CO}_{3}+3 \mathrm{H}_{2} \mathrm{O} \rightarrow 2 \mathrm{Cr}(\mathrm{OH})_{3} \downarrow+3 \mathrm{CO}_{2} \uparrow+6 \mathrm{NaNO}_{3} \text {. }
$$

The barium chromate sol was received as a result of ion-exchange reaction; it is a dispersed system in which the yellow fine-crystalline sediment 
precipitates. This sediment is soluble in the strong acids and insoluble in acetic acid:

$$
\begin{aligned}
& 2 \mathrm{BaCl}_{2}+\mathrm{K}_{2} \mathrm{Cr}_{2} \mathrm{O}_{7}+2 \mathrm{CH}_{3} \mathrm{COONa}+\mathrm{H}_{2} \mathrm{O} \rightarrow 2 \mathrm{BaCrO}_{4} \downarrow+2 \mathrm{KCl}+ \\
& +2 \mathrm{CH}_{3} \mathrm{COOH}+2 \mathrm{NaCl} .
\end{aligned}
$$

The main characteristics of aqueous solutions of sols were defined by physical and chemical methods of researches with use of conductometer, areometer, rotational viscometer and calculated methods (tab. 1). Dynamic viscosity of objects in time was investigated for definition of rheology type of aqueous solutions of sols: the Newtonian - value of viscosity does not change in time, the non-Newtonian - value of viscosity changes in time: increases - rheopectic, decreases - thixotropic. The studied objects № 2 and

\section{Table 1}

\begin{tabular}{|c|c|c|c|c|c|c|}
\hline $\begin{array}{l}\text { Type of colloidal } \\
\text { additive }\end{array}$ & $\begin{array}{l}\text { Hydrogen } \\
\text { ion } \\
\text { exponent, } \\
\text { pH }\end{array}$ & $\begin{array}{c}\text { Density of } \\
\text { sol by cal- } \\
\text { culation, } \rho_{\mathrm{s}}, \\
\mathrm{g} / \mathrm{cm}^{3}\end{array}$ & 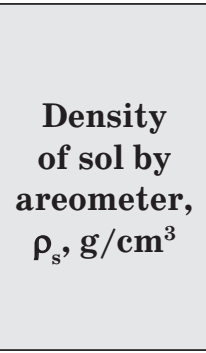 & $\begin{array}{l}\text { Electrical } \\
\text { conductiv- } \\
\text { ity, } \mu \mathrm{S}\end{array}$ & $\begin{array}{l}\text { Dynamic } \\
\text { viscosity, } \\
\text { sPz }\end{array}$ & $\begin{array}{l}\text { Content of } \\
\text { colloidal } \\
\text { particles in } \\
\text { the material } \\
\text { precipitated } \\
\text { from the sol, } \\
\% \text { (calcula- } \\
\text { tion) }\end{array}$ \\
\hline $\begin{array}{l}\text { Sulfur sol S, } \\
\text { received by solvent } \\
\text { substitution } \\
\text { method (№ 1) }\end{array}$ & $5-6$ & 0,9875 & 0,99 & 202 & $1,18 \pm 0,118$ & $4,25 \times 10^{-4}$ \\
\hline $\begin{array}{l}\text { Sulfur sol S, } \\
\text { received by redox } \\
\text { reaction (№ 2) }\end{array}$ & 1 & 0,976 & 0,98 & $>1000$ & $1,53 \pm 0,015$ & $1,06 \times 10^{-3}$ \\
\hline $\begin{array}{l}\text { Chromium } \\
\text { hydroxide sol } \\
\text { Cr(OH) })_{3} \text {, received } \\
\text { by ion-exchange } \\
\text { reaction (№ 3) }\end{array}$ & $10-11$ & 1,0945 & 1,084 & $>1000$ & $5,75 \pm 0,058$ & $2,74 \times 10^{-3}$ \\
\hline $\begin{array}{l}\text { Barium chromate } \\
\text { sol } \mathrm{BaCrO}_{4} \text {, } \\
\text { received by ion- } \\
\text { exchange reaction } \\
\text { (№ 4) }\end{array}$ & 5 & 1,0065 & 1,006 & $>1000$ & $1,72 \pm 0,017$ & $8,5 \times 10^{-4}$ \\
\hline
\end{tabular}

\section{The main characteristics of aqueous solutions of sols}


№ 3 are non-Newtonian liquids. Object № 2 exhibits properties of rheopectic systems, object № 3 exhibits thixotropic properties. Exemplars № 1 and № 4, most likely, fall into to the Newtonian liquids which are not changing the properties at the application of loading. Difference in rheological behavior of the studied objects is explained by their chemical composition.

Analyzing the received characteristics, it is possible to conclude:

- the density of chromium hydroxide sol and barium chromate sol exceed the value of density of water. It means that colloidal solution contain nanoparticles. Density of sulfur sols is less than $1 \mathrm{~g} / \mathrm{cm} 3$ because sulfur particles in the colloidal solution are easier than water;

- high electrical conductivity of sols demonstrated active surface of nanoparticles that probably promotes formation of additional structural component.

The optimum dosage of sols of various composition and methods of receiving were evaluated the compressing strength of specimens $2 \times 2 \times 2 \mathrm{~cm}$ of plastic forming with $\mathrm{W} / \mathrm{C}=0,26$. For comparison there were tested specimens on the basis of cement without additives - control specimens. The analysis of results of researches on optimization of the colloid additives dosages and kinetics of hardening of cement stone with their application showed that the optimum content of additives are: $0,8 \%$ for sulfur sol received by solvent substitution method and for chromium hydroxide sol; $1 \%$ - for the sulfur sol received as a result of redox reaction; $0,1 \%$ - barium chromate sol (fig. 1, tab. 2).

The specimens with sulfur sol at the age of 7 days received by solvent substitution method were exposed to drying at $t=150^{\circ} \mathrm{C}$ during 2 hours for imitation of cement stone hardening at the age of 28 days (tab. 2).

The analysis of received results showed that the optimum content of barium chromate sol is $0,1 \%$. It is equal $8,5 \times 10^{-4 \%}$ of dry matter equivalent(tab. 1, tab. 2).

At the same time it should be noted that effect of additives begins in early periods of hardening (1, 3 days) with increase of compressive strength from $14 \%$ to $45 \%$, therefore, all studied additives can be included in group of hardening-accelerating admixes of cement stone. The most effective additive is chromium hydroxide sol $\mathrm{Cr}(\mathrm{OH})_{3}$ at the dosage of $0,8 \%$. Increase of strength of cement stone at the age of 3 days is $45 \%$.

Drying of cement specimens with modifying additives at $t=150^{\circ} \mathrm{C}$ during 2 hours accelerates process of crystallization of gel which becomes 

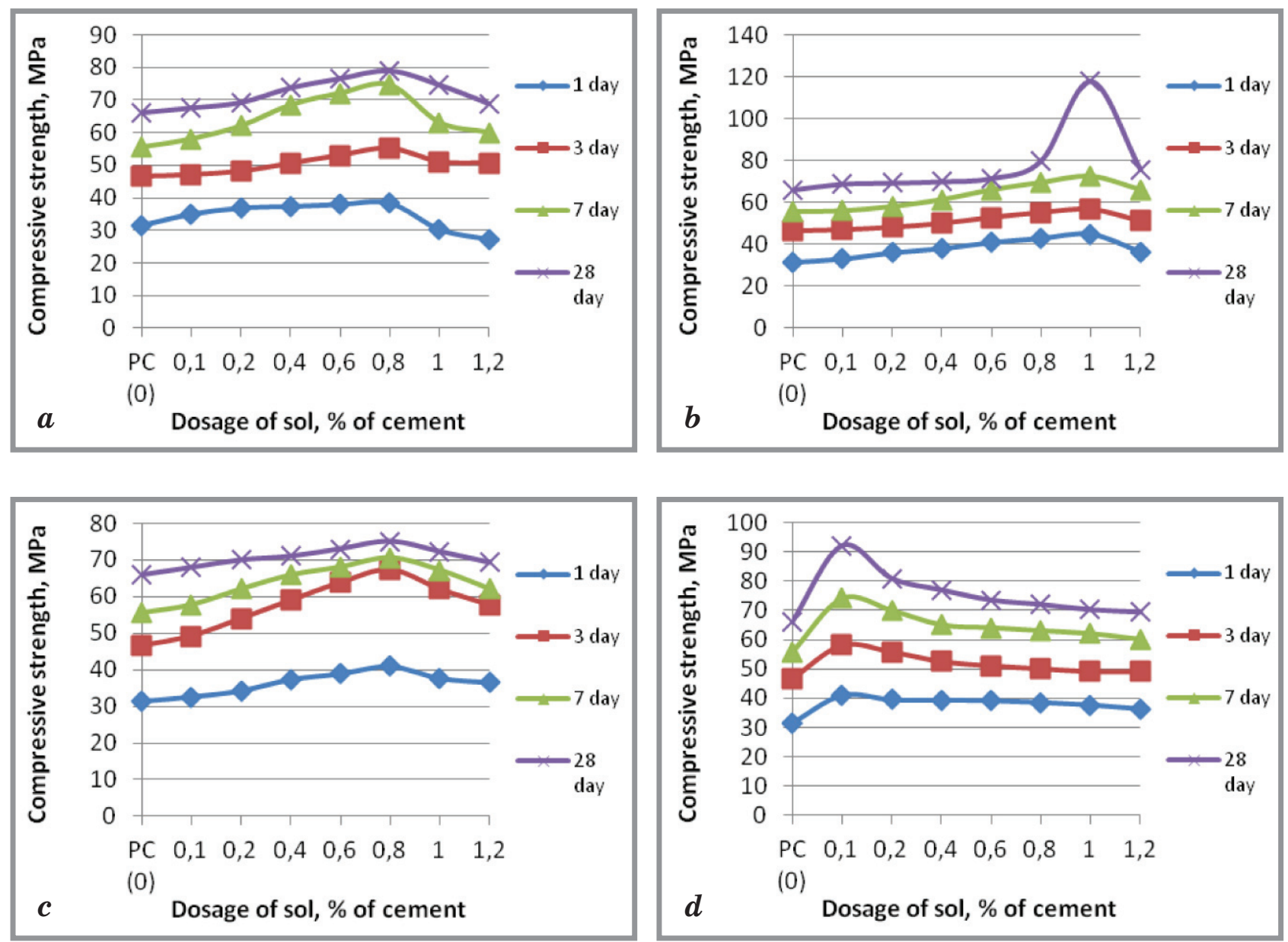

Fig. 1. The effect of type and dosage of sols on compressive strength of cement stone: $a-$ sulfur sol (solvent substitution method); b - sulfur sol (redox reaction); c-chromium hydroxide sol; $d$ - barium chromate sol.

additional structural component of cement matrix. It allows reducing time of hardening of PC.

The results of researches showed that sulfur sol received by redox reaction is the most effective additive. The optimum dosage of sulfur sol is $1 \%$ of cement mass. It is equal to $1,06 \times 10^{-3} \%$ of dry matter equivalent. Increase of strength of cement stone at the age of 28 days is $79 \%$. Hence, strength of cement stone increases at the microdosage of different composition sols.

The use of sols as modifying additives leads to change of cement stone structure (fig. 2). 


\section{The kinetics of strength setting of cement stone at the optimum content of different composition sols}

\begin{tabular}{|c|c|c|c|c|c|}
\hline \multirow{2}{*}{\multicolumn{2}{|c|}{ Data }} & \multicolumn{4}{|c|}{ Time of hardening $(\tau)$, days } \\
\hline & & \multirow{2}{*}{$\begin{array}{c}1 \\
31,4\end{array}$} & \multirow{2}{*}{$\begin{array}{c}3 \\
46,5\end{array}$} & \multirow{2}{*}{$\begin{array}{c}7 \\
55,5\end{array}$} & \multirow{2}{*}{$\begin{array}{c}28 \\
66\end{array}$} \\
\hline Control specimens & $\begin{array}{l}\text { Compressive strength Rc, } \\
\mathrm{MPa}\end{array}$ & & & & \\
\hline \multirow[b]{2}{*}{$\begin{array}{l}\text { Specimens with } 0,8 \% \\
\text { of the sulfur sol (solvent } \\
\text { substitution method) }\end{array}$} & $\begin{array}{l}\text { Compressive strength Rc, } \\
\mathrm{MPa}\end{array}$ & 38,3 & 55,1 & 74,5 & 79 \\
\hline & $\begin{array}{l}\text { Rc at the age of } 7 \text { days in } \\
\text { conditions of imitation of } \\
\text { hardening at the age of } 28 \\
\text { days }\left(t=150^{\circ} \mathrm{C}, \tau=2 \text { hours }\right) \text {, } \\
\operatorname{Rc}, \mathrm{MPa}\end{array}$ & - & - & $\begin{array}{c}82,3>79 \\
(\text { Rc } \\
28 \text { days })\end{array}$ & - \\
\hline Additive effect & $\mathrm{Rc} / \mathrm{Rc}$ cont. & 1,22 & 1,18 & 1,34 & 1,2 \\
\hline $\begin{array}{l}\text { Specimens with } 1 \% \text { of the } \\
\text { sulfur sol (redox reaction) }\end{array}$ & $\begin{array}{l}\text { Compressive strength } \mathrm{Rc} \text {, } \\
\mathrm{MPa}\end{array}$ & 45 & 56,6 & 72,5 & 118 \\
\hline Additive effect & $\mathrm{Rc} / \mathrm{Rc}$ cont. & 1,4 & 1,22 & 1,3 & 1,79 \\
\hline $\begin{array}{l}\text { Specimens with } 0,8 \% \text { of the } \\
\text { chromium hydroxide sol }\end{array}$ & $\begin{array}{l}\text { Compressive strength Rc, } \\
\mathrm{MPa}\end{array}$ & 39,3 & 67,4 & 70,5 & 75 \\
\hline Additive effect & $\mathrm{Rc} / \mathrm{Rc}$ cont. & 1,25 & 1,45 & 1,27 & 1,14 \\
\hline $\begin{array}{l}\text { Specimens with } 0,1 \% \text { of the } \\
\text { barium chromate sol }\end{array}$ & $\begin{array}{l}\text { Compressive strength Rc, } \\
\mathrm{MPa}\end{array}$ & 40,8 & 58,1 & 74,1 & 92,1 \\
\hline Additive effect & Rc/Rc cont. & 1,3 & 1,25 & 1,33 & 1,4 \\
\hline
\end{tabular}

The structure of control specimen at the age of 3 days has significant amount of pores, there is a portlandit in the form of large smooth surfaces, the crystals of ettringite in the form of long and short needles are visible (fig. 2, a). The microstructure of cement stone with sulfur sols received by solvent substitution method and method of redox reaction is more compact (fig. 2, b, c). The crystals of ettringite have form of needle. They are formed both near the surface of grains of tricalcium aluminate hydrate, and in intergrain space. The process of hardening and compaction of cement stone with sulfur sols is caused by formation of calcium aluminate sulfate hydrateat early stages of hardening [22]. Besides, compounds of sulfur disappear from liquid phase completely at hydration of tricalcium 

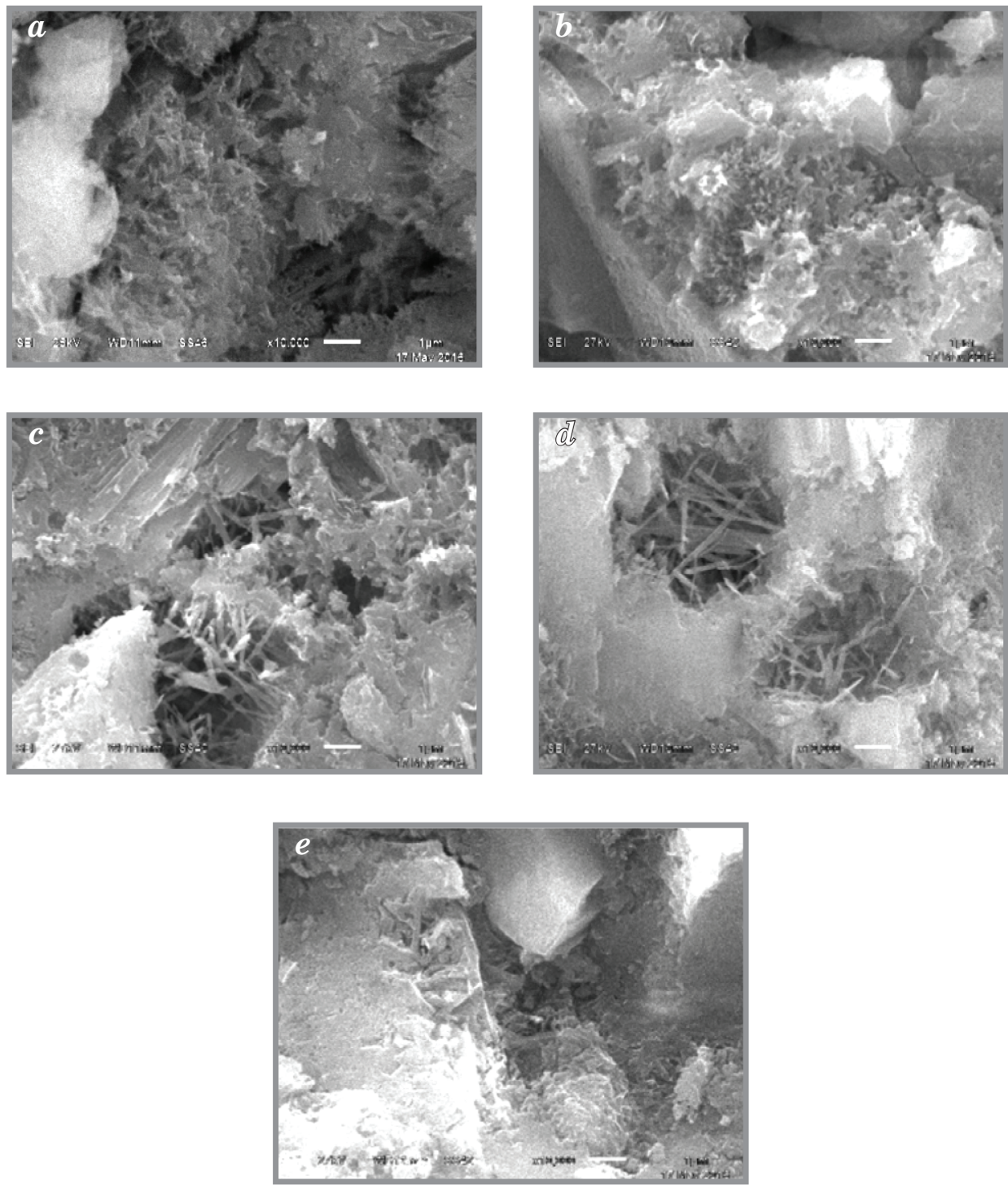

Fig. 2. The microstructure of cement stone (CS):

$\mathrm{a}$ - CS without additives (control specimen); b - CS with sulfur sol (solvent substitution method); c - CS with sulfur sol (redox reaction);

d - CS with chromium hydroxide sol; e-CS with barium chromate sol.

silicate and tetracalcium aluminaferrite in suspension at ratio of solid and fluid phases 1:3. The reduction reactions proceed on surface of solid phase that leads to formation of crystal sulfur and the difficult compounds of calcium containing sulfur [23-24].

The microstructure of cement stone with the additives contained chromium is also much more compact than microstructure of control specimen 
(fig. 2, d, e). Sols of barium chromate and chromium hydroxide activate hydration of cement stone and change of phase formation, influencing hydrogen ion concentration, i.e. they are acting on the hard acid principle. The ability of some substances to be an acceptor of electron pair and respectively proton donor or hard acid is reason of increasing of hydrogen ion concentration. Eventually this process in cement pastes is leveled due to hydration of silicates [25].

Thus, the use of sols on the basis sulfur and chromium compounds leads to compaction of cement stone structure that is why strength characteristics are improved. With that strength of cement increases at the microdosage of additives. The presented methods of receiving of different composition sols are available, simply in realization and rather cheap. It is possible to use these technologies in practice.

DeAR Colleagues!

THE REFERENCE TO THIS PAPER HAS THE FOLLOWING CITATION FORMAT:

Urkhanova L.A., Savelyeva M.A. The effect of different composition sols on change of structure and properties of cement stone. Nanotehnologii v stroitel'stve $=$ Nanotechnologies in Construction. 2016, Vol. 8, no. 6, pp. 20-42. DOI: dx.doi. org $/ 10.15828 / 2075-8545-2016-8-6-20-42$. 


\section{References:}

1. Bazhenov Yu.M., Falikman V.R., Bulgakov B.I. Nanomaterials and nanotechnologies in the modern technology of concrete. Vestnik MGSU. 2012, № 12, pp. 125-133. (In Russian).

2. Svatovskaya L.B., Solovyova V.Ya., Stepanova I.V., Starchukov D.S. Silica- and ferriferous(III) solnano-additives for heavy concrete on ordinary cements. Nanotehnologii v stroitel'stve $=$ Nanotechnologies in Construction. 2010, Vol.2, no. 5, pp. 61-68. URL: http//www.nanobuild.ru (date of the address: 17.09.2016). (In Russian).

3. Svatovskaya L.B., Sycheva A.M., Eliseyeva N.N. Improvement of quality of not autoclave concrete nanosize additives. Nanotehnologii v stroitel'stve $=$ Nanotechnologies in Construction. 2011, Vol. 3, no 1, pp. 50-52. URL: http//www.nanobuild.ru (date of the address: 22.09.2016). (In Russian).

4. Pat. 250550 Russian Federation IPC 8. C 04 B 28/04. C 04 BV 111/20. High-strength concrete / L.B. Svatovskaya, V.Ya. Solovyova, I.V. Stepanova, N.V. Ershikov, S.P. Kasatkin. No. 2012132785/03; declare 30.07.2012; publ. 27.01.2014. (In Russian).

5. Pat. 2515255 IPC 8. C 04 B 28/04. C 04 B 111/27. High-strength concrete / L.B. Svatovskaya, V.Ya. Solovyova, I.V. Stepanova, T.V. Smirnova, N.K. Korobov, D.S. Starchukov, D.V. Surin. No. 2012151469/03; declare 30.11.2012; publ.10.05.2014. (In Russian).

6. High-strength concrete on the basis of nanotechnology elements by a method sol-gel / P.G. Komokhov, L.B. Svatovskaya, V.Ya. Solovyova, A.M. Sycheva // Achievements, problems and the perspective directions of development of the theory and practice of structural materials science. Tenth Academic readings of RAACS. Kazan, 2006, pp. 8-9. (In Russian).

7. Komokhov P.G. Zol'-gel' kak koncepcija nanotehnologii cementnogo kompozita [Sol-gel as concept of nanotechnology of a cement composite]. Stroitel'nye materialy [Building materials]. 2006, No. 9, pp. 89-90. (In Russian).

8. Lukutsova N.P. Nanomodificirujushhie dobavki v beton [The nanomodifying additives in concrete]. Stroitel'nye materialy [Building materials]. 2010, No. 9, pp. 101-104. (In Russian).

9. Lukutsova N.P., Matveev E.G. The nanomodified compact-grained concrete. Proc. of reports of roundtable "Questions of application of nanotechnologies in construction". Moscow, 2009. P. 120. (In Russian).

10. Lukutsova N.P., Matveev E.G. Nanomodificirovannyj melkozernistyj beton [The nanomodified fine concrete]. Vestnik MGSU. 2009, No. 3, pp. 84-90. (In Russian).

11. Stepanova I.V. Development and application new the sol additives for upgrading of concrete of different density: synopsis of the thesis. Abstract of Ph.D. Thesis. St.Petersburg, 2004. 23 p. (In Russian).

12. Artamonova O.V., Sergutkina O.R., Korotkikh D.N., Chernyshov E.M. Sol-gel synthesis of nanodimensional particles of $\mathrm{SiO}_{2}$ for modifying of cement stone structure. Nanotehnologii v stroitel'stve = Nanotechnologies in Construction. 2010, Vol. 2, № 1, pp. 97-105. URL: http//www.nanobuild.ru (date of the address: 25.09.2016). (In Russian). 
13. Artamonova O.V., Chernyshev E.M. Koncepcii i osnovanija tehnologij nanomodificirovanija struktur stroitel'nyh kompozitov [Concepts and bases of nanomodifying technologies of structural composites structures]. Stroitel'nye materialy [Building materials]. 2013, No. 9, pp. 82-90. (In Russian).

14. Artamonova O.V., Sergutkina O.R. Issledovanie kolichestvennogo sostava nanorazmernyh sistem $\mathrm{SiO}_{2}-\mathrm{H}_{2} \mathrm{O}$, sintezirovannyh zol'-gel' metodom [A research of the quantitative structure of the nanodimensional $\mathrm{SiO}_{2}-\mathrm{H}_{2} \mathrm{O}$ systems synthesized by sol-gel method]. Nauchnyj vestnik VGASU. 2011, No. 3-4, pp. 14-20. (In Russian).

15. Kuzmina V.P. Influence mechanisms of nanoadditives on cement products. Nanotehnologii v stroitel'stve $=$ Nanotechnologies in Construction. 2011, Vol. 3, no. 6, pp. 85-95. URL: http//www.nanobuild.ru (date of the address: 30.09.2016). (In Russian).

16. Kuzmina V.P. Perspektivy primenenija nanotehnologij v stroitel'stve. Chast' 1 [The prospects of application of nanotechnologies in construction. Part 1.]. Tehnologii betonov [Concrete Technologies]. 2009, No. 11-12, pp. 46-48. (In Russian).

17. Kuzmina V.P. Perspektivy primenenija nanotehnologij v stroitel'stve. Chast' 2 [The prospects of application of nanotechnologies in construction. Part 2.]. Tehnologii betonov [Concrete Technologies]. 2010, No. 1-2, pp. 50-52. (In Russian).

18. Dorzhiyeva E.V. The modified concrete by silica-acid sol. Abstract of Ph.D. Thesis. UlanUde, 2013. 20 p. (In Russian).

19. Dorzhiyeva E.V., Gonchikova E.V., Arkhincheeva N.V. The researches of influence of solgel processes on properties of a cement stone. Nanotehnologii v stroitel'stve $=$ Nanotechnologies in Construction. 2011, № 6, pp. 66-73. URL: http//www.nanobuild.ru (date of the address: 01.10.2016). (In Russian).

20. Dorzhiyeva E.V. Nanomodificirovanie cementnogo kamnja vvedeniem mnogokomponentnogo zolja [Nanomodifying of a cement stone by introduction of multicomponent sol]. E.V. Gonchikova, N.V. Arkhincheeva, E.V. Dorzhiyeva. Stroitel'nye materialy [Building materials]. 2011, No. 9, pp. 68-69. (In Russian).

21. Pat. 2440313 of the Russian Federation C 04 B 28/04; High-strength concrete / E.V. Gonchikova., N.V. Arkhincheeva, E.V. Dorzhiyeva, Z.M. Gonchikov. No. 2010124758/03; declare16.06.2010; publ. 20.01.2012. (In Russian).

22. Sychev A.A. A complex sulfopolymeric additive for cement compositions. Abstract of Ph.D. Thesis, Kazan, 2005. 146 p. (In Russian).

23. Pavlov A.V. Heavy concrete with complex sulfur-polymeric additives. Abstract of Ph.D. Thesis, Novosibirsk, 2005. 140 p. (In Russian).

24. Pat. 2167116 Russian FederationIPC 7. C 04 B 22/14. Complex additive for concrete and mortar mixes / Pavlov A.V., Gulyaev M.N., Elesin M.A., Mashkin N.A., Belousov S.V. No. 99115797/03; declare 15.07.1999; publ. 20.05.2001. (In Russian).

25. Sychev M.M., Svatovskaya L.B. Aktivirovannoe tverdenie cementov [Activated hardening of cements]. Moscow, Stroiizdat, 1983. 160 p. (In Russian). 
Автор: УРХАНОВА Лариса Алексеевна, д-р техн. наук, профессор, заведующая кафедрой «Производство строительных материалов и изделий», Восточно-Сибирский государственный университет технологий и управления; ул. Ключевская, 40в, г. Улан-Удэ, Российская Федерация, 670013, urkhanova@mail.ru;

Автор: САВЕЛЬЕВА Марина Александровна, аспирант, Восточно-Сибирский государственный университет технологий и управления; ул. Ключевская, 40в, г. Улан-Удэ, Российская Федерация, 670013, senya160394@mail.ru

\section{ВЛИЯНИЕ ЗОЛЕЙ РАЗЛИЧНОГО СОСТАВА НА ИЗМЕНЕНИЕ СТРУКТУРЫ И СВОЙСТВ ЦЕМЕНТНОГО КАМНЯ}

АННОТАЦИЯ К СТАТЬЕ (АВТОРСКОЕ РЕЗЮМЕ, РЕФЕРАТ):

В строительном материаловедении одним из стремительно развивающихся направлений является применение нанотехнологии для разработки бетонов нового поколения. $K$ настоящему времени широкое применение в технологии бетона получили нанодисперсные добавки, позволяющие повысить его основные физико-механические свойства. Использование эффективных добавок, содержащих в своем составе наночастицы, позволяет оптимизировать структуру бетона, а также снизить расход самого дорогостоящего компонента - цемента. Необходимость создания новых доступных и относительно недорогих модификаторов цементных и бетонных изделий обусловлена большими затратами ресурсов, сложностью их получения, следовательно, высокой себестоимостью и, соответственно, ценой на рынке.

В статье рассмотрены вопросы получения добавок в виде золей на основе химических соединений элементов VI группы периодической системы Д.И. Менделеева, в частности серы и хрома, а также их использование для модификации цементного камня. С помощью физико-химических методов исследований и расчетных способов были определены основные характеристики водных растворов золей. В результате проведенных экспериментальных исследований было оптимизировано содержание коллоидных добавок в цементном камне, установлена кинетика набора его прочности в зависимости от вида и количества золей. Содержание золей в цементном камне составляет тысячные доли от массы вяжущего, то есть повышение его прочности происходит на микроуровне. Это представляет собой существенную экономию полученных добавок при их введении в цементные и бетонные композиции. Использова- 
ние добавок золей на основе соединений серы и хрома не только ускорило гидратацию и твердение цемента в ранние сроки твердения, но и значительно улучшило прочностные характеристики цементного камня. Полученные нанодисперсные добавки можно отнести к группе добавок-ускорителей твердения цемента. Повышение прочности цементного камня, модифицированного золями различного состава, связано с изменением его структуры. Электронно-микроскопический анализ показал, что применение золей различного состава в качестве модификаторов приводит к уплотнению микроструктуры цементного камня и образованию сложных соединений серы и хрома с гидросиликатами кальция.

Ключевые слова: золь серы, золь гидроксида хрома, золь хромата бария, гидратация и твердение, микроструктура, цементный камень, прочность при сжатии.

DOI: dx.doi.org/10.15828/2075-8545-2016-8-6-20-42

МАШИНОЧИТАЕМАЯ ИНФОРМАЦИЯ О СС-ЛИЦЕНЗИИ В МЕТАДАННЫХ СТАТЬИ (HTML-КОД):

$<$ a rel="license" href="http://creativecommons.org/licenses/by/4.0/" ><img alt="Лицензия Creative Commons" style="border-width:0" src="https://i.creativecommons.org/l/by/4.0/88x31.png" $/></ \mathrm{a}><$ br $/>$ Произведение "<span xmlns:dct="http://purl.org/dc/terms/" href="http://purl.org/dc/dcmitype/Text" property="dct:title" $\mathrm{rel}=$ "dct:type" $>$ Влияние золей различного состава на изменение структуры и свойств цементного камня $</ \operatorname{span}>$ » $\operatorname{co3-}$ данное автором по имени <a xmlns:cc="http://creativecommons.org/ns\#" href="Нанотехнологии в строитель стве. 2016. - Toм 8, № 6. - C. 20-42. - DOI: dx.doi.org/10.15828/2075-8545-2016-8-6-20-42" property="cc:attributionName" re l="cc:attributionURL"> Урханова Л.А., Савельева M.А.</a>, публикуется на условиях <a rel="license" href="http:// creativecommons.org/licenses/by/4.0/">лицензии Creative Commons «Attribution» ( ААтрибуция») 4.0 Всемирная $<$ / a $>$. $<$ br $/>$ Основано на произведении с $<$ a xmlns:dct="http://purl.org/dc/terms/" href="http://nanobuild.ru/ru_RU/ nanobuild-6-2016/" rel="dct:source">http://nanobuild.ru/ru_RU/nanobuild-6-2016/</a >.<br />Разрешения, выходящие за рамки данной лицензии, могут быть доступны на странице $<$ a xmlns:cc="http://creativecommons.org/ns\#" href="urkhanova@mail.ru" rel="cc:morePermissions">urkhanova@mail.ru</a>.

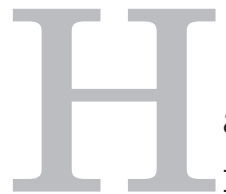

а сегодняшний день все больший интерес вызывает использование в цементных композициях и бетонах золь-гель технологий для повышения их основных строительно-технических свойств: морозостойкости, прочности, водонепроницаемости, снижения усадочных деформаций [1]. К настоящему времени появилось значительное количество добавок на основе золя кремниевой кислоты, золя гидроксида железа, гидроксида алюминия, применение которых позволяет получать высокопрочные бетоны за счет изменения структуры материала. 
Большой вклад в изучение данного направления внесли такие ученые, как М.М. Сычев, П.Г. Комохов, Л.Б. Сватовская, Н.П. Лукутцова и др., которые получали в основном однокомпонентные золи и применяли их для модификации цемента и бетона [2-17]. Авторами [18-21] были получены золи, включающие в свой состав одновременно золь кремнекислоты, золь гидроксида железа, золь гидроксида алюминия. При этом ими были разработаны способы получения золей за счет обменных реакций между солями многовалентных металлов.

При анализе периодической системы Д.И. Менделеева было выявлено, что на сегодняшний день мало исследований посвящено получению золей на основе химических элементов VI группы. В составе VI группы имеются химические элементы, соединения которых при гидролизе или в результате обменных реакций образуют золи различного состава и стабильности. Авторами статьи проведены исследования по модификации цементного камня золями различного состава, среди которых интерес представляют химические соединения серы и хрома, поскольку они являются доступными и относительно дешевыми.

Золь серы представляет собой нанодисперсную коллоидную систему, получение которой возможно двумя методами: окислительновосстановительной реакцией и методом замены растворителя. По последнему методу насыщенный раствор серы прибавляют понемногу к жидкости, которая хорошо смешивается с растворителем, например, с ацетоном или этиловым спиртом, но плохо с водой.

Получение золя серы методом окислительно-восстановительной реакции происходит при взаимодействии сильных кислот с тиосульфатом натрия, в результате образуется свободная тиосерная кислота, распадающаяся с выделением элементарной серы:

$$
\begin{aligned}
& 2 \mathrm{HCl}+\mathrm{Na}_{2} \mathrm{~S}_{2} \mathrm{O}_{3} \rightarrow 2 \mathrm{NaCl}+\mathrm{H}_{2} \mathrm{~S}_{2} \mathrm{O}_{3} . \\
& \mathrm{H}_{2} \mathrm{~S}_{2} \mathrm{O}_{3} \rightarrow \mathrm{S}+\mathrm{H}_{2} \mathrm{O}+\mathrm{SO}_{2} \uparrow .
\end{aligned}
$$

Образование золя гидроксида хрома (III) происходит в результате реакции ионного обмена полного - необратимого гидролиза, протекающего при смешении растворов двух солей, усиливающих гидролиз друг друга. Выпадение осадка происходит с выделением углекислого газа, в результате образуется мутновато-зеленый золь гидроксида хрома (III): 


$$
2 \mathrm{Cr}\left[((\mathrm{NO})]_{3}\right)_{3}+3 \mathrm{Na}_{2} \mathrm{CO}_{3}+3 \mathrm{H}_{2} \mathrm{O} \rightarrow 2 \mathrm{Cr}(\mathrm{OH})_{3} \downarrow+3 \mathrm{CO}_{2} \uparrow+6 \mathrm{NaNO}_{3} \text {. }
$$

Золь хромата бария был получен в результате реакции ионного обмена, он представляет собой дисперсную систему, в которой выпадает желтый мелкокристаллический осадок, растворимый в сильных кислотах, но не растворимый в уксусной кислоте:

$$
\begin{aligned}
& 2 \mathrm{BaCl}_{2}+\mathrm{K}_{2} \mathrm{Cr}_{2} \mathrm{O}_{7}+2 \mathrm{CH}_{3} \mathrm{COONa}+\mathrm{H}_{2} \mathrm{O} \rightarrow 2 \mathrm{BaCrO}_{4} \downarrow+2 \mathrm{KCl}+ \\
& +2 \mathrm{CH}_{3} \mathrm{COOH}+2 \mathrm{NaCl} .
\end{aligned}
$$

С помощью физико-химических методов исследований с использованием кондуктометра, ареометра, ротационного вискозиметра и расчетных способов были определены основные характеристики исследуемых золей (табл. 1). Для определения типа реологии водных растворов

\begin{tabular}{|c|c|c|c|c|c|c|}
\hline $\begin{array}{c}\text { Вид коллоидной } \\
\text { добавки }\end{array}$ & $\begin{array}{l}\text { Водород- } \\
\text { ный пока- } \\
\text { затель, pH }\end{array}$ & 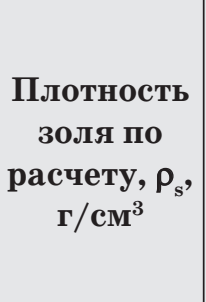 & 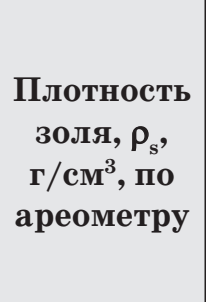 & $\begin{array}{c}\text { Удельная } \\
\text { электро- } \\
\text { провод- } \\
\text { ность, } \mu \mathrm{S}\end{array}$ & $\begin{array}{c}\text { Динами- } \\
\text { ческая } \\
\text { вязкость, } \\
\text { сПз }\end{array}$ & $\begin{array}{c}\text { Содержание } \\
\text { коллоидных } \\
\text { частиц в } \\
\text { материале, } \\
\text { осажденном } \\
\text { из золя, \% } \\
\text { (расчет) }\end{array}$ \\
\hline $\begin{array}{l}\text { Золь серы S, получен- } \\
\text { ный методом замены } \\
\text { растворителя (№ 1) }\end{array}$ & $5-6$ & 0,9875 & 0,99 & 202 & $1,18 \pm 0,118$ & $4,25 \times 10^{-4}$ \\
\hline $\begin{array}{l}\text { Золь серы S, получен- } \\
\text { ный методом окисли- } \\
\text { тельно-восстанови- } \\
\text { тельной реакции (№ 2) }\end{array}$ & 1 & 0,976 & 0,98 & $>1000$ & $1,53 \pm 0,015$ & $1,06 \times 10^{-3}$ \\
\hline $\begin{array}{l}\text { Золь гидроксида хро- } \\
\text { ма Сr(OH) } \\
\text {, получен- } \\
\text { ный методом реакции } \\
\text { ионного обмена (№ 3) }\end{array}$ & $10-11$ & 1,0945 & 1,084 & $>1000$ & $5,75 \pm 0,058$ & $2,74 \times 10^{-3}$ \\
\hline $\begin{array}{l}\text { Золь хромата бария } \\
\mathrm{BaCrO}_{4} \text {, полученный } \\
\text { методом реакции ион- } \\
\text { ного обмена (№ 4) }\end{array}$ & 5 & 1,0065 & 1,006 & $>1000$ & $1,72 \pm 0,017$ & $8,5 \times 10^{-4}$ \\
\hline
\end{tabular}

Таблища 1

\section{Основные характеристики водных растворов золей}


золей была исследована динамическая вязкость объектов во времени: ньютоновская - значение вязкости не изменяется во времени, неньютоновская - значение вязкости изменяется во времени: увеличивается реопексная, уменьшается - тиксотропная. Исследуемые объекты № 2 и № 3 относятся к неньютоновским жидкостям: № 2 проявляет свойства реопексных систем, а образец № 3 - тиксотропные свойства. Образцы № 1 и № 4, вероятнее всего, относятся к ньютоновским жидкостям, не изменяющим своих свойств при приложении нагрузки. Различие в реологическом поведении исследуемых образцов объясняется их химическим составом.

Анализируя полученные характеристики, можно сделать вывод:

- плотность золя гидроксида хрома и хромата бария превышает значение плотности воды, что означает присутствие наночастиц в кол-

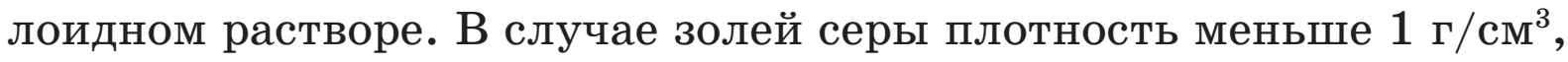
поскольку сами частицы серы, распределенные в коллоидном растворе, легче воды;

- высокая удельная электропроводность золей свидетельствует об активной поверхности наночастиц, что предположительно способствует созданию дополнительного структурного элемента.

Оптимальную дозировку золей различного состава и способа получения оценивали по пределу прочности при сжатии образцов $2 \times 2 \times 2 \mathrm{~cm}$ пластичного формования с В/Ц = 0,26. Для сравнения испытывались образцы на основе бездобавочного цемента - контрольные образцы. Анализ результатов исследований по оптимизации дозировок коллоидных добавок и кинетики твердения цементного камня с их применением показал, что оптимальным содержанием добавок являются: 0,8\% для золя серы, полученного методом замены растворителя, и для золя гидроксида хрома; 1\% - для золя серы, полученного в результате окислительно-восстановительной реакции; $0,1 \%$ - для золя хромата бария (рис. 1, табл. 2).

Для имитации твердения цементного камня в возрасте 28 суток образцы с золем серы, полученного методом замены растворителя, в возрасте 7 суток подвергались сушке при $t=150^{\circ} \mathrm{C}$ в течение 2 часов (табл. 2).

Анализ полученных результатов показал, что в случае использования золя хромата бария оптимальное содержание коллоидной добавки составляет $0,1 \%$, что в пересчете на сухое вещество равно $8,5 \times 10^{-4} \%$ (табл. 1, табл. 2). 

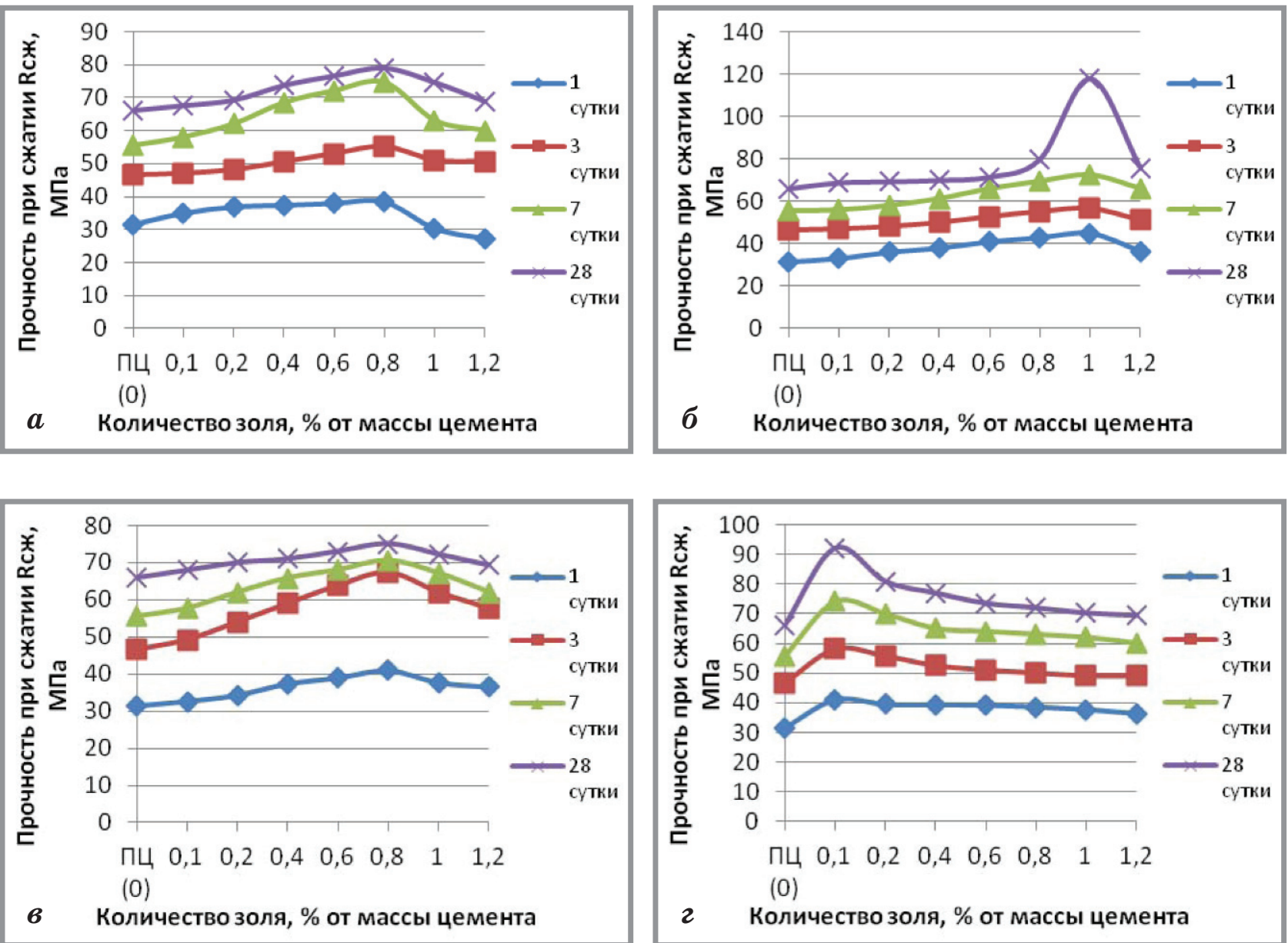

Рuc. 1. Влияние вида и количества золей на прочность цементного камня: a - золь серы (метод замены растворителя); б - золь серы (метод окислительновосстановительной реакции);в - золь гидроксида хрома; г-золя хромата бария

При этом следует отметить, что эффективность действия добавок начинается в ранние сроки твердения $(1,3$ суток) с увеличением прочности с 14\% до 45\%, следовательно, все исследуемые добавки являются ускорителями твердения цементного камня. Наиболее эффективная добавка - золь гидроксида хрома $\mathrm{Cr}(\mathrm{OH})_{3}$ при дозировке 0,8\%. Прирост прочности ПЦ в 3 суток составляет $45 \%$.

Сушка образцов цемента с модифицирующими добавками при $\mathrm{t}=150^{\circ} \mathrm{C}$ в течение 2 часов ускоряет процесс выкристаллизации геля, который становится дополнительным структурным элементом цементной матрицы, что в целом позволяет сократить время твердения ПЦ. 
Таблица 2

\section{Кинетика набора прочности цементного камня при оптимальном содержании золей различного состава}

\begin{tabular}{|c|c|c|c|c|c|}
\hline \multirow{2}{*}{\multicolumn{2}{|c|}{ Показатели }} & \multicolumn{4}{|c|}{ Время $(\tau)$ твердения, сутки } \\
\hline & & \multirow{2}{*}{$\frac{1}{31,4}$} & \multirow{2}{*}{$\begin{array}{c}3 \\
46,5\end{array}$} & \multirow{2}{*}{$\begin{array}{c}7 \\
55,5\end{array}$} & \multirow{2}{*}{$\frac{28}{66}$} \\
\hline Контрольные образцы & $\begin{array}{l}\text { Прочность при сжатии } \\
\text { Rсж, МПа }\end{array}$ & & & & \\
\hline \multirow[b]{2}{*}{$\begin{array}{l}\text { Образцы с 0,8\% золь серы } \\
\text { (замена растворителя) }\end{array}$} & $\begin{array}{l}\text { Прочность при сжатии } \\
\text { Rсж, МПа }\end{array}$ & 38,3 & 55,1 & 74,5 & 79 \\
\hline & $\begin{array}{l}\text { Rсж в } 7 \text { сут. в усл. имита- } \\
\text { ции тверд. } 28 \text { сут. } \\
\left(\mathrm{t}=150^{\circ} \mathrm{C}, \tau=2 \text { часа }\right) \\
\text { Rсж, МПа }\end{array}$ & - & - & $\begin{array}{l}82,3>79 \\
\text { (Rсж } \\
28 \text { сут.) }\end{array}$ & - \\
\hline Эффективность добавки & Rсжсд/Rсжконт. & 1,22 & 1,18 & 1,34 & 1,2 \\
\hline $\begin{array}{l}\text { Образцы с 1\% золь серы } \\
\text { (окислительно-восстано- } \\
\text { вительная реакция) }\end{array}$ & $\begin{array}{l}\text { Прочность при сжатии } \\
\text { Rсж, МПа }\end{array}$ & 45 & 56,6 & 72,5 & 118 \\
\hline Эффективность добавки & Rсжсд/Rсжконт. & 1,4 & 1,22 & 1,3 & 1,79 \\
\hline $\begin{array}{l}\text { Образцы с } 0,8 \% \text { золь } \\
\text { гидроксида хрома }\end{array}$ & $\begin{array}{l}\text { Прочность при сжатии } \\
\text { Rсж, МПа }\end{array}$ & 39,3 & 67,4 & 70,5 & 75 \\
\hline Эффективность добавки & Rсжсд/Rсжконт. & 1,25 & 1,45 & 1,27 & 1,14 \\
\hline $\begin{array}{l}\text { Образцы с } 0,1 \% \text { золь } \\
\text { хромата бария }\end{array}$ & $\begin{array}{l}\text { Прочность при сжатии } \\
\text { Rсж, МПа }\end{array}$ & 40,8 & 58,1 & 74,1 & 92,1 \\
\hline Эффективность добавки & Rсжсд/Rсжконт. & 1,3 & 1,25 & 1,33 & 1,4 \\
\hline
\end{tabular}

По результатам исследований полученный методом окислительно-восстановительной реакции золь серы с оптимальной дозировкой $1 \%$ является самой эффективной модифицирующей добавкой. При содержании добавки в цементном камне в пересчете на сухое вещество $1,06 \times 10^{-3} \%$ прирост прочности в 28 суток составил $79 \%$. Следовательно, прирост прочности при сжатии цементного камня начинается при микродозировках золей различного состава.

Использование золей в качестве модифицирующих добавок приводит к изменению структуры цемента (рис. 2).

В структуре бездобавочного цементного камня (контрольного состава) в возрасте 3 суток присутствует значительное количество пор, 

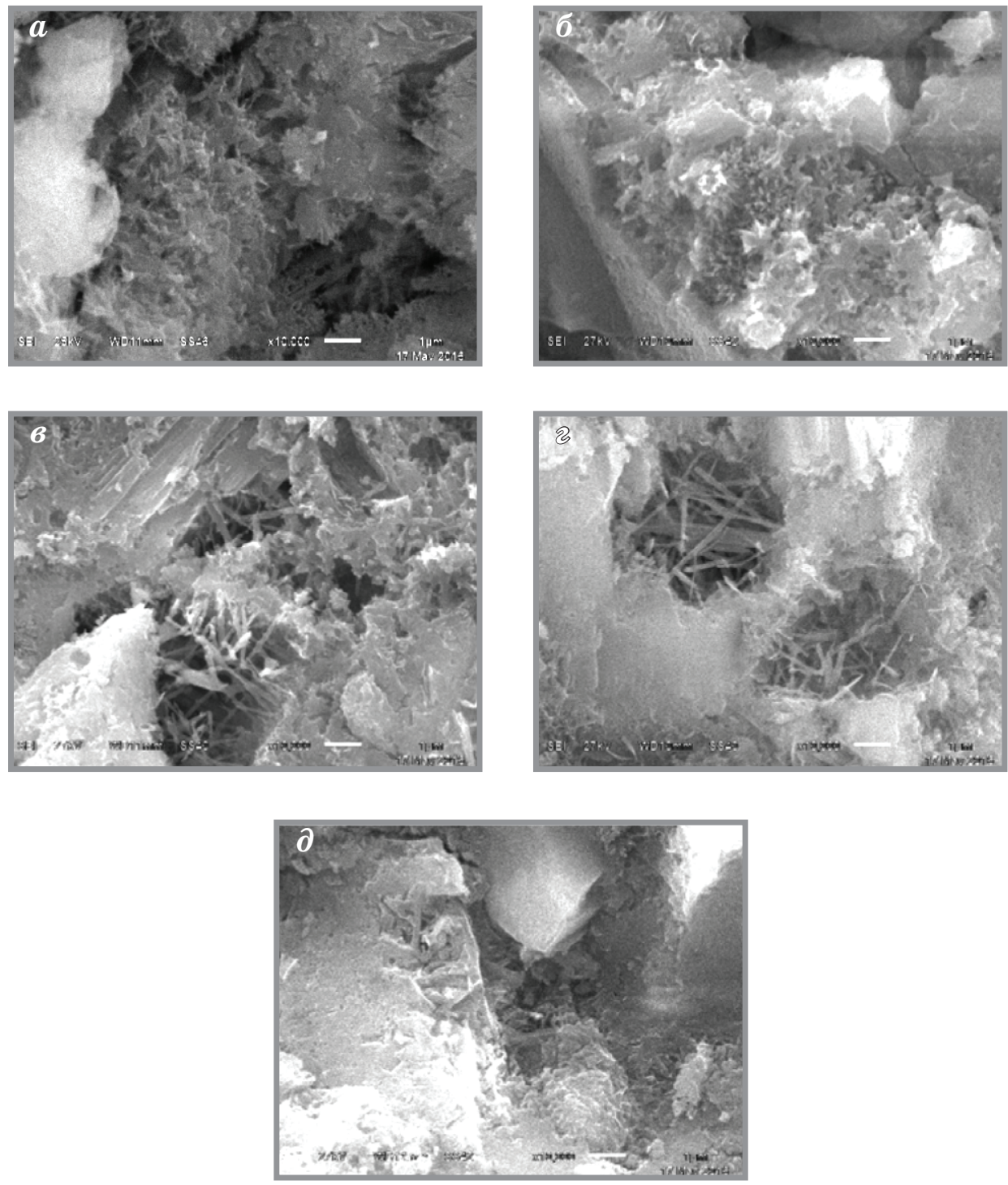

Рис. 2. Микроструктура цементного камня (ЦК):

a - бездобавочный ЦК (контрольный образец); б - ЦК с золем серы (метод замены растворителя); в - ЦК с золем серы (метод окислительно-восстановительной реакции); г - ЦК с золем хромата бария; д - ЦК с золем гидроксида хрома

портландит в виде массивных гладких поверхностей, видны кристаллы эттрингита разной формы: длинные и короткие игольчатые кристаллы (рис. 2 а). Микроструктура цементного камня с золями серы, полученными методами замены растворителя и окислительно-восстановительной реакции, более плотная (рис. 2 б, в). Кристаллы эттрингита имеют игольчатую форму и образуются как вблизи поверхности зерен трехкальциевого гидроалюмината, так и в межзерновом пространстве. 
Процесс упрочнения и уплотнения цементного камня с добавками золя серы обусловлен формированием на ранних стадиях твердения гидросульфоалюминатов [22]. Кроме того, при гидратации трехкальциевого силиката и четырехкальциевого алюмоферрита в суспензии при соотношении твердой и жидкой фаз 1:3 соединения серы исчезают из жидкой фазы полностью. На поверхности твердой фазы протекают восстановительные реакции, что приводит к образованию кристаллической серы и сложных соединений кальция, содержащих серу [23-24].

Микроструктура цементного камня с добавками, содержащими хром, также заметно более плотная, чем у контрольного образца (рис. 2 г, д). Золи хромата бария и гидроксида хрома активируют гидратацию цементного камня и меняют фазоообразование, воздействуя на концентрацию ионов водорода, т.е. действуют по принципу твердых кислот. Причиной повышения концентрации ионов водорода в начальный момент может служить способность некоторых веществ быть акцептором электронных пар и соответственно донором протона или твердой кислотой. Со временем в цементных пластах этот процесс нивелируется благодаря гидратации силикатов [25].

Таким образом, использование золей на основе соединений серы и хрома приводит к уплотнению структуры цементного камня, вследствие чего улучшаются прочностные характеристики. При этом повышение прочности цемента происходит при микродозировках добавок. Представленные способы получения золей различного состава являются доступными, простыми в выполнении и относительно дешевыми, что представляет возможным применение данных технологий на практике. 


\section{УВАЖАЕМЫЕ КОЛЛЕГИ!}

ПРИ ИСПОЛЬЗОВАНИИ МАТЕРИАЛА ДАННОЙ СТАТЬИ

ПРОСИМ ДЕЛАТЬ БИБЛИОГРАФИЧЕСКУЮ ССЫЛКУ НА НЕЁ:

Урханова Л.А., Савельева М.А. Влияние золей различного состава на изменение структуры и свойств цементного камня // Нанотехнологии в строительстве. - 2016. - Том 8, № 6. - C. 20-42. - DOI: dx.doi.org/10.15828/2075-85452016-8-6-20-42.

\section{DeAr Colleagues!}

THE REFERENCE TO THIS PAPER HAS THE FOLLOWING CITATION FORMAT:

Urkhanova L.A., Savelyeva M.A. The effect of different composition sols on change of structure and properties of cement stone. Nanotehnologii v stroitel'stve = Nanotechnologies in Construction. 2016, Vol. 8, no. 6, pp. 20-42. DOI: dx.doi. org/10.15828/2075-8545-2016-8-6-20-42.

\section{Библиографический список:}

1. Наноматериалы и нанотехнологии в современной технологии бетонов / Ю.М. Баженов, В.Р. Фаликман, Б.И. Булгаков // Вестник МГСУ. - 2012. № 12. - C. 125-133.

2. Сватовская Л.Б., Соловьева В.Я., Степанова И.В., Старчуков Д.С. Нанодобавки из кремне- и железосодержащего (III) золя для тяжелого бетона на рядовых цементах // Нанотехнологии в строительстве. - 2010. - Т. 2., № 5. - С. 61-68. URL: http //www.nanobuild.ru (дата обращения: 17.09.2016).

3. Сватовская Л.Б., Сычева А.М., Елисеева Н.Н. Повышение качества неавтоклавного бетона добавками наноразмера // Нанотехнологии в строительстве. 2011. - T. 3, № 1. - C. 50-52. - URL: http //www.nanobuild.ru (дата обращения: 22.09.2016).

4. Сватовская Л.Б., Соловьева В.Я., Степанова И.В., Ершиков Н.В., Касаткин С.П. Высокопрочный бетон // Патент России № 2012132785/03. 250550 РФ МПК 8. С 04 В 28/04. С 04 В 111/20. заяв. 30.07.2012; опубл. 27.01.2014. 
5. Сватовская Л.Б., Соловьева В.Я., Степанова И.В., Слирнова Т.В., Коробов Н.К., Старчуков Д.С., Сурин Д.В. Высокопрочный бетон // Патент России № 2012151469/03. 2515255 МПК 8. С 04 В 28/04. С 04 В 111/27. заяв. 30.11.2012; опубл. 10.05.2014.

6. Высокопрочный бетон на основе элементов нанотехнологии по методу зольгель / П.Г. Комохов, Л.Б. Сватовская, В.Я. Соловьева, А.М. Сычева // Достижения, проблемы и перспективные направления развития теории и практики строительного материаловедения. Десятые Академические чтения РАACH. Казань, 2006. - С. 8-9.

7. Колохов П.Г. Золь-гель как концепция нанотехнологии цементного композита // Строительные материалы. - 2006. - № 9. - С. 89-90.

8. Лукутиова Н.П. Наномодифицирующие добавки в бетон / Строительные материалы. - 2010. - № 9. - С. 101-104.

9. Лукутиова Н.П. Наномодифицированный мелкозернистый бетон / Н.П. Лукутцова, Е.Г.Матвеева // Вопросы применения нанотехнологий в строительстве: сб. докладов участников круглого стола. - М., 2009. - С. 120.

10. Лукутиова Н.П. Наномодифицированный мелкозернистый бетон / Н.П. Лукутцова, Е.Г. Матвеева // Вестник МГСУ. - 2009. - № 3. - С. 84-90.

11. Степанова И. В. Разработка и применение новых зольсодержащих добавок для повышения качества бетона разной плотности: автореф. дис. ... канд. техн. наук. - СПб., 2004. - 23 с.

12. Арталонова О.В., Сергуткина О.Р., Коротких Д.Н., Чернышов Е.М. Золь-гель синтез наноразмерных частиц $\mathrm{SiO}_{2}$ для модифицирования структуры цементного камня // Нанотехнологии в строительстве. - 2010. - Т. 2, № 1. - С. 97105. - URL: http //www.nanobuild.ru (дата обращения: 25.09.2016).

13. Арталонова O.В. Концепции и основания технологий наномодифицирования структур строительных композитов / О.В. Артамонова, Е.М. Чернышев // Строительные материалы. - 2013. - № 9. - С. 82-90.

14. Арталонова О.В., Сергуткина О.Р. Исследование количественного состава наноразмерных систем $\mathrm{SiO}_{2}-\mathrm{H}_{2} \mathrm{O}$, синтезированных золь-гель методом // Научный вестник ВГАСУ. - 2011. - № 3-4. - С. 14-20.

15. Кузьлина В.П. Механизмы воздействия нанодобавок на цементные продукты // Нанотехнологии в строительстве. - 2011. - Т. 3, № 6. - С. 89-95. - URL: http //www.nanobuild.ru (дата обращения: 30.09.2016).

16. Кузьлина В.П. Перспективы применения нанотехнологий в строительстве. Часть 1 // Технологии бетонов. - 2009. - № 11-12. - С. 46-48. 
17. Кузьлина В.П. Перспективы применения нанотехнологий в строительстве. Часть 2 // Технологии бетонов. - 2010. - № 1-2. - С. 50-52.

18. Доржиева E.B. Бетоны, модифицированные золем кремнекислоты: автореф. дисс...канд.техн.наук. - Улан-Удэ, 2013. - 20 с.

19. Доржиева E.B. Исследования влияния золь-гель процессов на свойства цементного камня / Е.В. Доржиева, Е.В. Гончикова, Н.В. Архинчеева // Нанотехнологии в строительстве. - 2011. - Т. 3, № 6. - С. 66-73. - URL: http //www. nanobuild.ru (дата обращения: 01.10.2016).

20. Доржиева E.B. Наномодифицирование цементного камня введением многокомпонентного золя / Е.В. Гончикова, Н.В. Архинчеева, Е.В. Доржиева // Строительные материалы. - 2011. - № 9. - С. 68-69.

21. Гончикова Е.В., Архинчеева Н.В., Доржиева Е.В., Гончиков З.М. Высокопрочный бетон // Патент России № 2440313. РФС04В 28/04. №2010124758/03; заяв. 16.06.2010; опубл. 20.01.2012.

22. Сычев A.A. Комплексная сульфополимерная добавка для цементных композиций: дис. ... канд. техн. наук. - Казань, 2005. - 146 с.

23. Павлов А.В. Тяжелые бетоны с комплексными сернисто-полимерными добавками: дис. ... канд. техн. наук. - Новосибирск, 2005. - 140 с.

24. Павлов А.В., Гуляев М.Н., Елесин М.А., Машкин Н.А., Белоусов С.В. Комплексная добавка для бетонных и растворных смесей // Патент России № 99115797/03. 2167116 РФ МПК 7. С 04 В 22/14. заяв. 15.07.1999; опубл.20.05.2001.

25. Сычев М.М., Сватовская Л.Б. Активированное твердение цементов. - М.: Стройиздат, 1983. - 160 с. 